\title{
RELATIONSHIP BETWEEN OPTICAL MICROSCOPIC STRUCTURE AND PHYSICAL CHARACTERIZATION OF ORGANIC WASTES ORIGINATED PEAT SUBSTITUTES
}

\author{
DEDE, O. H. ${ }^{*}-$ OZTEKIN, M. H. \\ Department of Environmental Engineering, Engineering Faculty, Sakarya University \\ 54187 Sakarya, Turkey \\ (ohdede@sakarya.edu.tr,+90-264-295-5761; hazeloztekn@gmail.com,+90-544-270-0643) \\ *Corresponding author \\ e-mail: ohdede@sakarya.edu.tr, phone: +90-264-295-5761; fax: +90-264-346-0633
}

(Received 20 $0^{\text {th }}$ Oct 2017; accepted $12^{\text {th }}$ Feb 2018)

\begin{abstract}
The aim of the study was to determine relationship between the microscopic structure and physical characterization of organic wastes which have a potential as a substrate occurred during the agricultural and industrial activities. The microscopic structure of the samples was observed using scanning electron microscope (SEM). Physical properties were specified according to EU standards using the methods from the existing literature. According to the results of this study the organic waste samples show difference in decomposing depending on their surface and internal structure. Micro pores are prevailing in the waste with higher decomposing rate (HH, SMC, MWC), while the waste with lower decomposing rate (TW, MS, RH) has higher content of macro pores. When the pore diameter of the samples increases, their porosity and air capacity raise as well, but their water holding capacity decreases. Best results were determined at hazelnut husk and the insufficient results were obtained at rice hull. Comparing the physical properties obtained with the desired ideal values for the growing medium indicates that hazelnut husk, sawdust, spend mushroom compost and municipal solid waste compost can be used as pure and that other organic wastes can be used in the mixtures as growth medium components. Keywords: soilless growing media, potting media, internal structure, physical properties, waste reclamation
\end{abstract}

\section{Introduction}

Serious problems are experienced in the management and disposal of organic wastes, as significant types of waste both in the rural and urban areas, due to their various types and high amounts. On the other hand, agricultural wastes generated particularly in rural areas are released into forests and stream beds or tried to be disposed by burning. This in turn causes the contamination of water resources, air pollution, release of pathogen microorganisms and odor problems. (Dede et al., 2006). Yet, with their high organic matter and plant nutrient content these wastes can be utilized in vegetative production, the most ecologic and sustainable method of disposal. The literature includes many studies demonstrating that agricultural-based organic wastes can be successfully utilized in vegetative production, where it is reported that their utilization as growth medium particularly in the cultivation of potted ornamental plants would constitute a significant alternative to natural soil and peat (Apaolaza et al., 2005; Rigane et al., 2011; Belda et al., 2013).

The basic properties sought in growth media to be used in the cultivation of potted ornamental plants are high stability in order to allow the roots to anchor and support the plant, good hydraulic properties in order to supply water to the plant, the ability to supply the roots with the needed air and containing various plant nutrients (Tariq et al., 2012). Considering the fact that plant nutrient content can be improved by means of 
simple applications such as using natural or artificial fertilizers, the suitability of the physical and hydrophysical properties of organic materials would be determinative in its stability as growth medium (Abad et al., 2001; Yahya et al., 2010).

Generally, growing mediums are classified according to their hydraulic properties. In this classification, growing media is divided into four types (Yahya et al., 2010). Type 1: aerated growing media with high water availability and high water buffering capacity, Type 2: less aerated growing media with average to high water availability, Type 3: highly aerated growing media with low water availability, and Type 4: growing media with low water availability but a very low water buffering capacity.

On the other hand, the physical and hydraulic properties of the materials used as growing media can often be controlled by particle size distribution. However, in some cases different physical and hydraulic properties can be seen in growing media with similar particle size distributions (Abad et al., 2001; Ozdemir et al., 2015). This can be attributed to differences in surface and interior structures of the growing media.

This study aims to explain the effects of surface and internal structure of organic wastes on physical and hydraulic properties and to determine the usability of organic wastes examined as growing media.

\section{Materials and methods}

\section{Organic wastes sampling}

Organic waste samples that could be used as a growing media analyzed in this study have been collected from different regions of Turkey. In the selection of organic wastes we have taken into account if the waste has been created in great amounts directly during agricultural production or as a result of processing of agricultural products, if other purpose cannot be found for it and if it has a specific decomposing stability. As a result of these criteria it has been decided that Hazelnut Husk (HH), Maize straw (MS), Pine Bark (PB), Tea waste (TW), Saw dust (WW), Rice Hull (RH), Spend Mushroom Compost (SMC), Municipal waste compost (from Istanbul municipal composting facility) (MWC) will be used in this study. From the collected samples hazelnut husk and maize straw were processed by a shredder machine, while for the other samples it was not deemed necessary. Also, by comparing the analyzed samples to Sphagnum peat and to the characteristics considered ideal for growing media by the written literature we tried to specify the possibility of its use as a growing media.

\section{Scanning electron microscope (SEM) analysis}

The surface and internal structure of the samples were observed using scanning electron microscope (SEM) (JEOL - JSM - 6060 LV Model). SEM images of the samples were taken at $1000 x-3000 x$ magnifications for analysis. The samples were spurted a film of gold, about $5 \mathrm{~nm}$ thick, to enhance their conductivity before characterization by means of SEM.

Cold stage has been applied in order to prevent the samples from changing their shape as a result of high vacuum in SEM. On the other hand, in order to be certain that the structure of the sample was not damaged three replicates of each material have been made during the preparation of samples and the images obtained from them have been compared to each other (Fornes et al., 2007; Guo and Liu, 2007; Masaphy et al., 2009). 


\section{Physical and physicochemical properties}

In order to put forth the characterization of the waste samples used in the study, physical and physicochemical properties were specified according to European Union standards using the methods from the existing literature.

Particle size distribution in the samples was found by drying them on $35{ }^{\circ} \mathrm{C}$ and putting them in the electromagnetic digital vibrating sieve set (CISA model 002) that used a series of different sieves with $16,8,4,2,1,0.5,0.25$ and $0.125 \mathrm{~mm}$ gaps and by measuring peaces remaining in each sieve after $10 \mathrm{~min}$ of sieving. The index of particle sizes CI (Coarseness index), geometric average of particle diameters $\left(\mathrm{d}_{\mathrm{g}}\right)$ and geometric deviations $\left(\sigma_{\mathrm{g}}\right)$ were calculated using the obtained results and below-mentioned equations (Eqs. 1, 2, 3 and 4). Pieces larger than $1 \mathrm{~mm}$ were taken into account while calculating CI (Abad et al., 2005; Richards et al., 1986).

$$
\begin{gathered}
C I=\sum \% \mathrm{Pi} ; \mathrm{i}>1 \mathrm{~mm} \\
\mathrm{~d}_{\mathrm{g}}=\exp (\mathrm{a}) \\
\mathrm{a}=\sum_{\mathrm{i}} \mathrm{m}_{\mathrm{i}} \ln \mathrm{d}_{\mathrm{i}} \\
\sigma_{\mathrm{g}}=\exp \sqrt{\sum_{\mathrm{i}} \mathrm{m}_{\mathrm{i}}\left(\ln \mathrm{d}_{\mathrm{i}}\right)^{2}-\mathrm{a}^{2}}
\end{gathered}
$$

$\mathrm{m}_{\mathrm{i}}=$ weight of particles put in the sieve,

$\mathrm{d}_{\mathrm{i}}=$ average diameter of two consecutive sieves.

In accordance with the EU standards specific weights of samples were determined by using $\%$ of organic matter and \% of the ash content (mineral matter). Volume weights, in accordance with the EU standards, were found by measuring the dry weight of samples in a known volume after it has been kept under $10 \mathrm{~cm}$ suction pressure in a water column. Total porosity was calculated using the $\%$ rate of pore volume within the mass of the certain weight of samples (Volume-Weight). The air capacity was found by measuring the loss that resulted from the water saturation of the samples and their drainage under $10 \mathrm{~cm}$ pressure.

Volumetric shrinkage of organic waste samples was found by drying the samples on $105^{\circ} \mathrm{C}$ and expressing in percents the volume loss caused by the drying process. Water holding capacity was measured by submerging the samples in water, holding them under $10 \mathrm{~cm}$ pressure and then determining the amount of water left in the samples. Wettability, in accordance with Australian Standard (2003), was determined by measuring the amount of time needed for the dried samples to absorb $10 \mathrm{ml}$ of pure water.

Water suspension method was used in order to determine $\mathrm{pH}$ value and electrical conductivity of the selected organic waste. $\mathrm{pH}$ was determined, in accordance with the EU standards, by putting the material prepared in 1:5 ratio into pure water suspension and measuring its $\mathrm{pH}$ with a glass electrode $\mathrm{pH}$-meter (European Standard, Une-En 13037). Total organic matter content was calculated in percents by heating the dried $\left(105^{\circ} \mathrm{C}\right)$ sample in a furnace on $550^{\circ} \mathrm{C}$ for $4 \mathrm{~h}$ (Benito et al., 2006). 
All data was analyzed statistically using analysis of variance (F-test) at $\mathrm{P} \leq 0.05$ and means of the treatments were compared by the Least Significant Difference (LSD) at $\mathrm{P}=0.05$.

\section{Results and discussion}

It is known that the analysis of the pore structure provides important information about growing media, its hydraulic characteristics, air capacity and degradation level (Marianthi et al., 2006). This is why SEM analysis was used in this study to facilitate understanding of hydraulic and physical characteristics of the samples by examining surface and internal structure of the organic waste samples whose potential to be used as a growing media is being investigated. The results are presented in Figure 1. Since SEM figures examined both surface and internal structure they can be divided into two groups. The samples with advanced decomposing formed the first group; spend mushroom compost, municipal waste compost and peat. They possess a very small number of macro pores and a homogeneous spread of micro pores. Hazelnut husk samples, despite having low decomposition rate, resemble this group very much. The second group we will introduce includes slow decomposing samples such as maize straw, rice hull, tea waste and saw dust whose structure, especially the internal one, is full of macro pores.
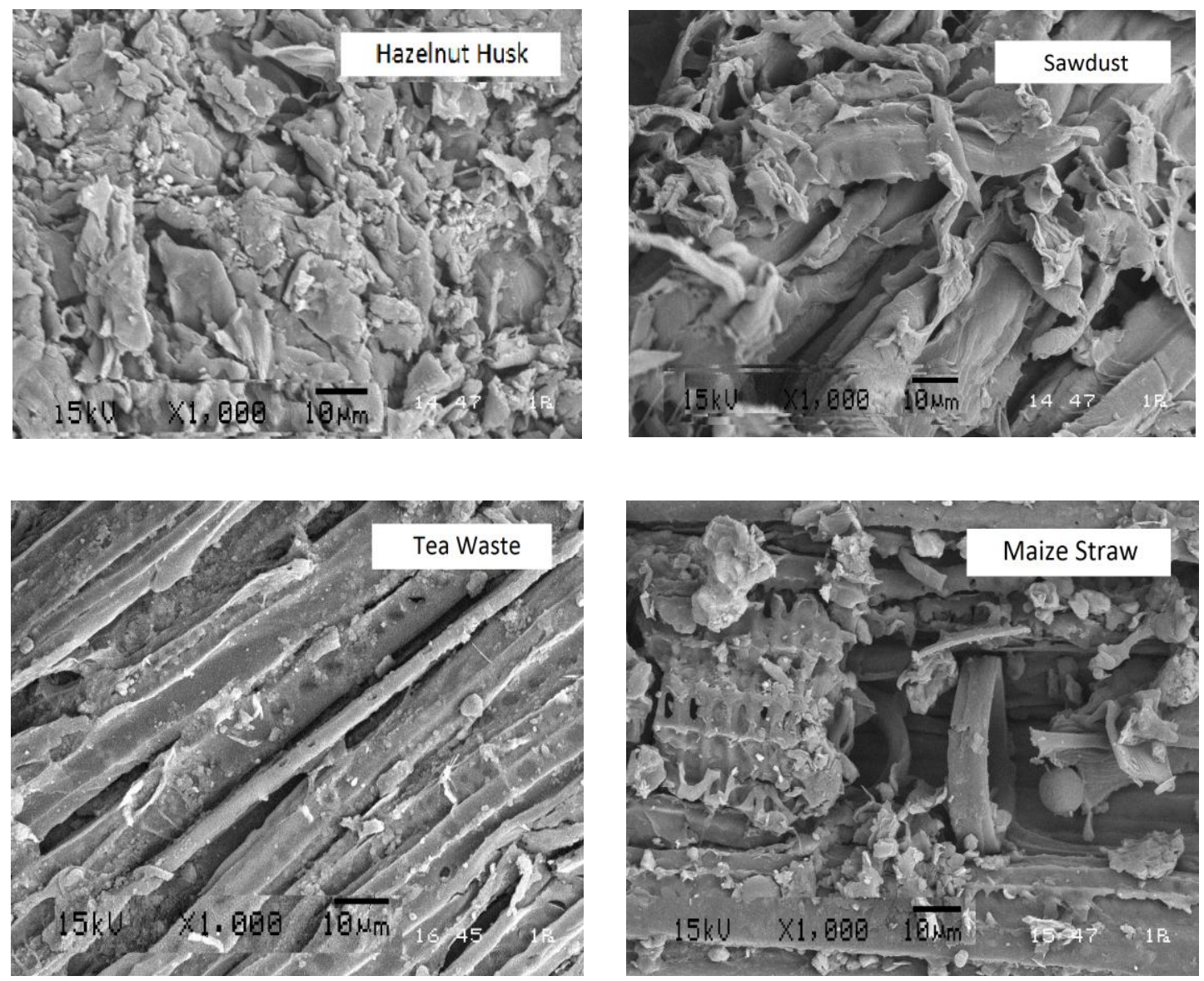

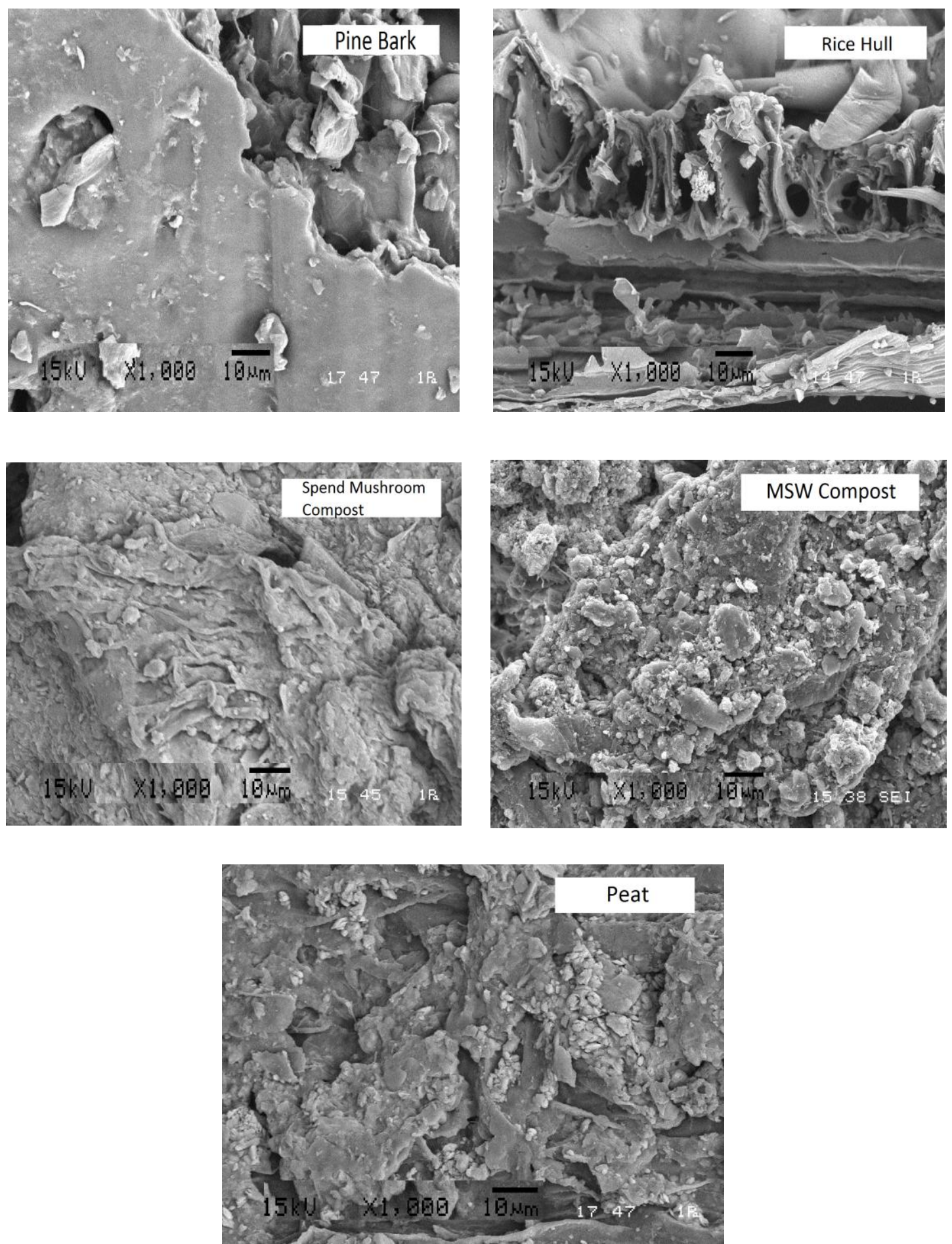

Figure 1. Scanning electron microscope (SEM) micrographs of the surface and interval structure of the organic waste samples, MSV compost and peat

Even though it is also connected to porosity and particle size distribution, the difference in two groups' hydraulic properties can be clearly understood from their surface and internal characteristics. When the pore diameter of the samples increases, 
their gravitational water drainage and air capacity raises as well, but its water holding capacity decreases. Contrary to that, when the pore diameter of the samples decreases, its water holding capacity goes up, while the air capacity goes down (Fornes et al., 2003). Applying composting that would significantly increase decomposition rate of wastes such as maize straw, tea waste and rice hull, would be suitable for its use as a growing media because it would change the surface and internal structure of the waste and thus improve its hydraulic properties.

Even though we can use SEM figures to obtain information important for understanding the hydraulic properties of the samples through analyzing its surface and internal structure, the analysis of particle size distribution can help us understand the differences of the physical characteristics of samples that share similar structure (Ozdemir et al., 2015). By analyzing organic waste samples' particle sizes we can see that maize straw and rice hull (2-4 $\mathrm{mm})$ are mostly composed of bigger particles, while municipal waste, pine bark and saw dust $(0.5-2 \mathrm{~mm})$ are mostly composed of smaller particles. However, tea waste, hazelnut husk, waste mushroom compost and peat samples' particle size distribution tends to stay within 1-4 mm, thus we can say that they are composed of a homogeneous mixture of big, middle sized and small particles (Fig. 2).
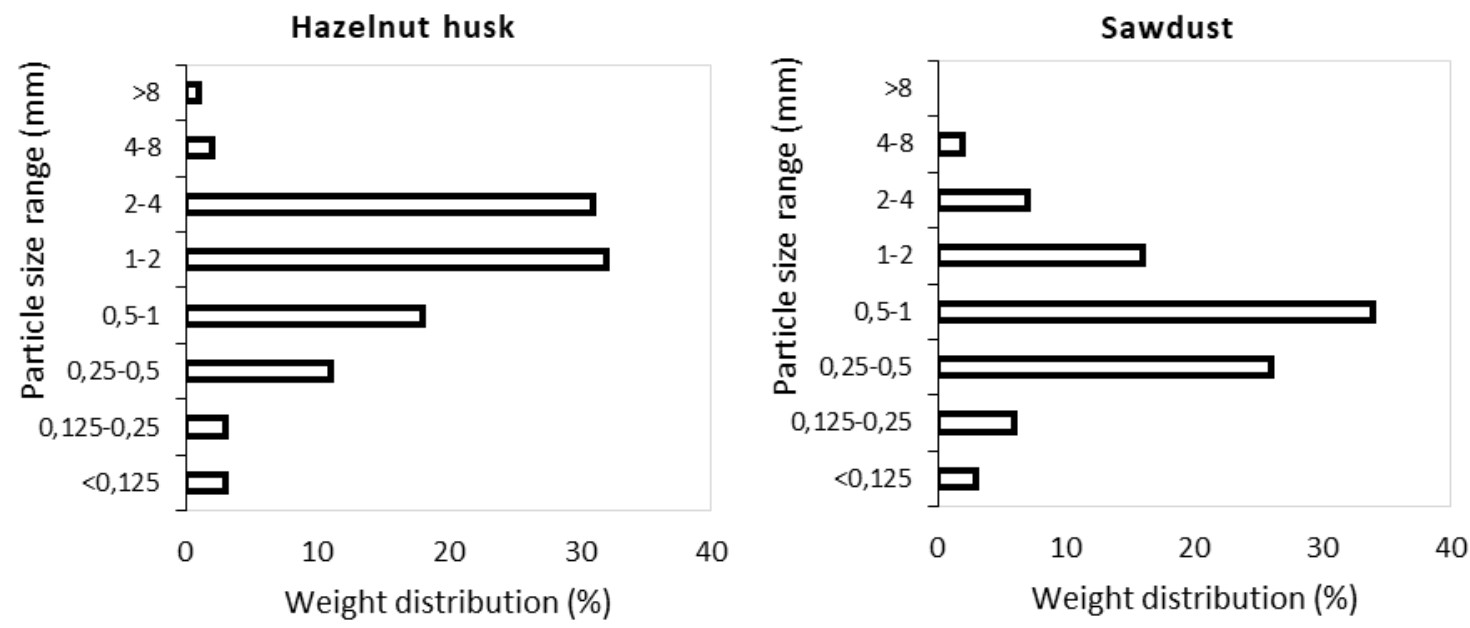

Tea waste
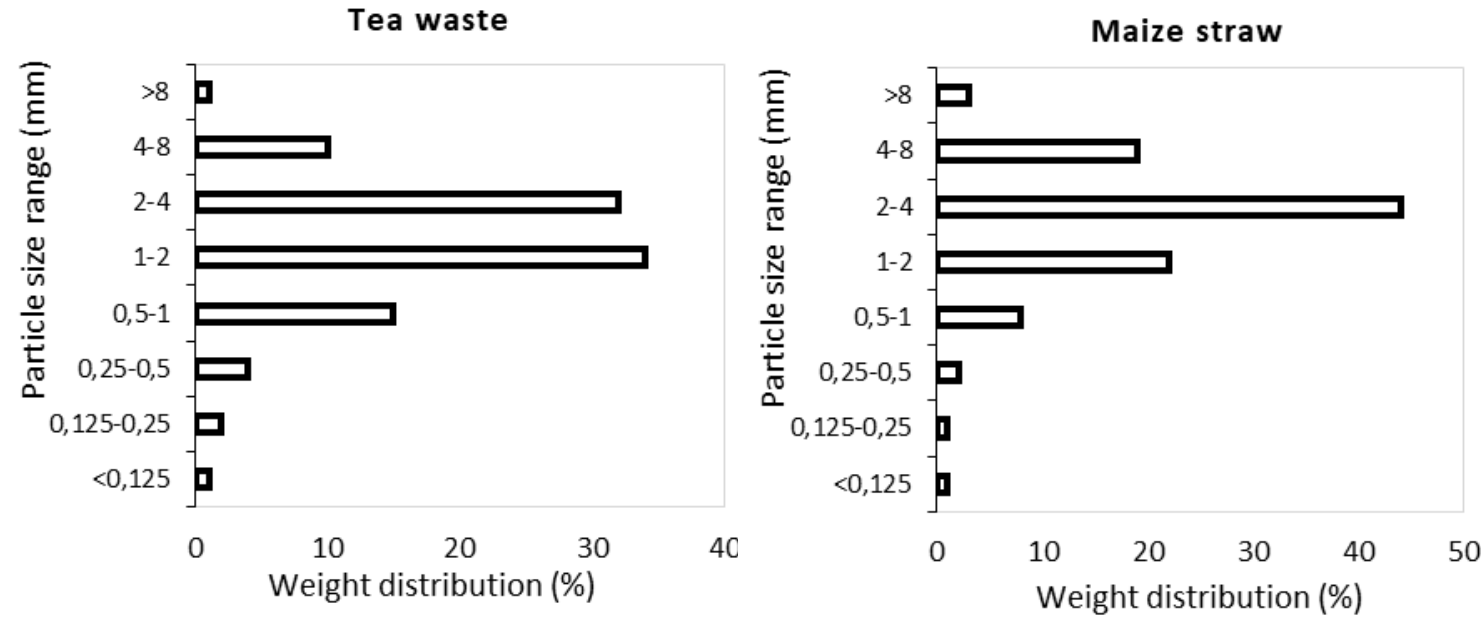

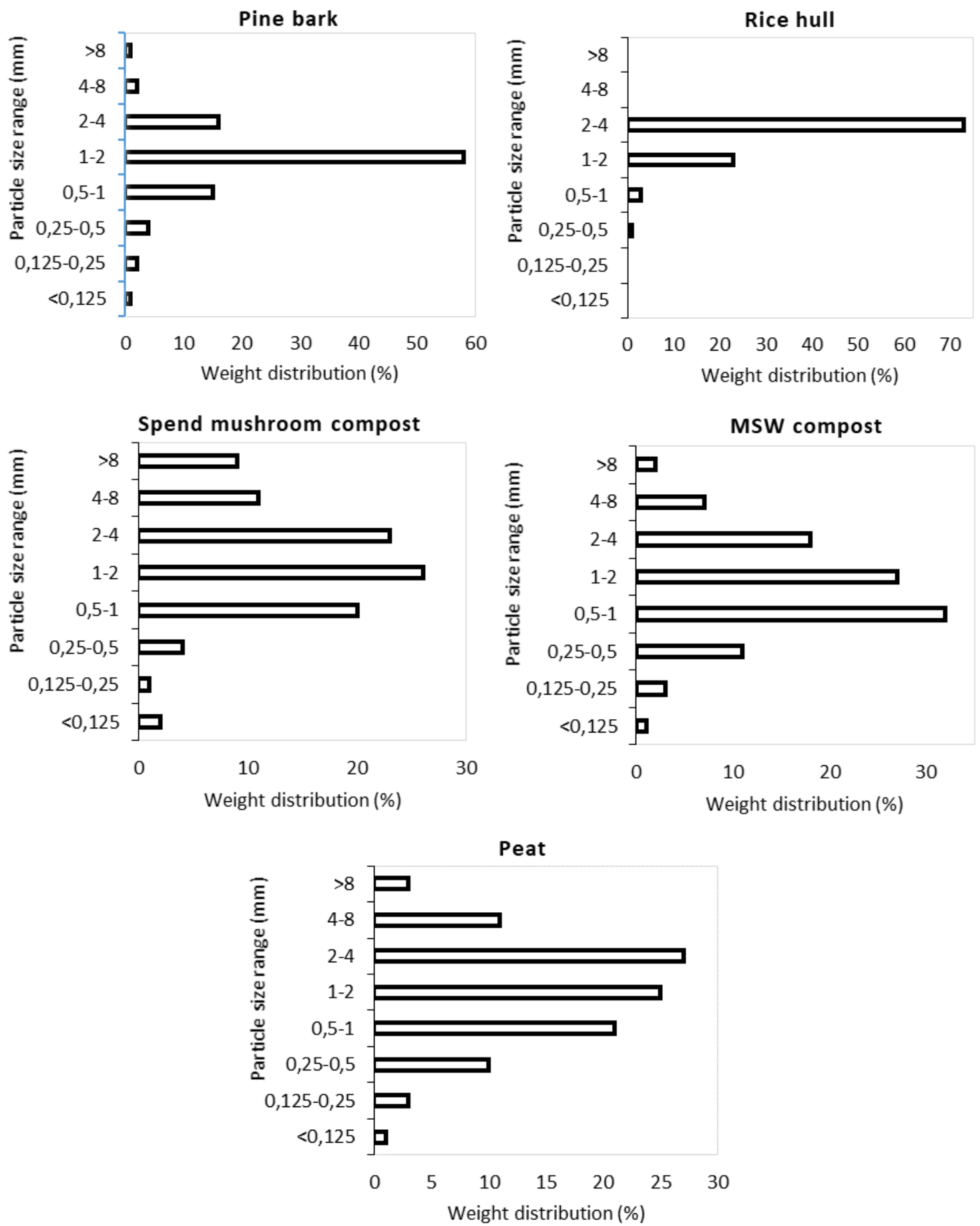

Figure 2. Particles size distribution of organic waste samples, MSW compost and peat

According to the calculations of organic waste samples' index of particle sizes (CI), geometric average and the standard deviation of geometric average while taking into account particles bigger than $1 \mathrm{~mm}$ when calculating, the rice hull has the highest CI value of 96, while saw dust has the lowest CI value of 25 (Table 1). Hazelnut husk (66) and peat (66.67) were found to have similar results when calculating index of particle sizes. 
When the values of particle size distribution on Shape 1 and CI, Dg, og values in Table 1 are analyzed together, we can say that maize straw and spend mushroom compost need to be subjected to additional fragmentation of large particles, while rice hull, compost and saw dust can be used in a mixture with growing media with large particles. Hazelnut husk and peat can be used as a growing media without adding anything (Abad et al., 2003).

Table 1. Particle size index (CI), geometric average of sample particle size, standard deviation of geometric average calculated from particle size distribution in organic waste samples, MSW compost and peat

\begin{tabular}{c|c|c|c}
\hline Samples & CI (\%V/V) & Dg & og \\
\hline Hazelnut husk & $66 \mathrm{e}^{*}$ & $1.269 \mathrm{~g}$ & $2.625 \mathrm{c}$ \\
Sawdust & $25 \mathrm{~g}$ & $0.698 \mathrm{i}$ & $2.342 \mathrm{e}$ \\
Tea waste & $77 \mathrm{c}$ & $1.733 \mathrm{~d}$ & $2.316 \mathrm{f}$ \\
Maize straw & $88 \mathrm{~b}$ & $2.462 \mathrm{a}$ & $2.284 \mathrm{~g}$ \\
Pine bark & $78 \mathrm{c}$ & $1.392 \mathrm{f}$ & $2.013 \mathrm{~h}$ \\
Rice hull & $96 \mathrm{a}$ & $2.404 \mathrm{~b}$ & $1.496 \mathrm{i}$ \\
Spend Mushroom Compost & $73 \mathrm{~d}$ & $1.841 \mathrm{c}$ & $2.846 \mathrm{a}$ \\
MSW compost & $54 \mathrm{f}$ & $1.226 \mathrm{~h}$ & $2.529 \mathrm{~d}$ \\
Peat & $66.6 \mathrm{e}$ & $1.542 \mathrm{e}$ & $2.707 \mathrm{~b}$ \\
\hline
\end{tabular}

*Data followed by the same letter are not different at $\mathrm{p}=0.05$

The results of other physical properties analyzed in this study are presented in Tables 2 and 3. According to these results municipal waste compost has the highest volume weight $\left(0.649 \mathrm{~g} / \mathrm{cm}^{3}\right)$ and specific weight $\left(2.089 \mathrm{~g} / \mathrm{cm}^{3}\right)$, while the lowest values of volume weight $\left(0.05 \mathrm{~g} / \mathrm{cm}^{3}\right)$ and specific weight $\left(1.474 \mathrm{~g} / \mathrm{cm}^{3}\right)$ were found in maize straw. While composting municipal solid waste, even if waste decomposing process is applied, it will be mixed with a significant amount of inorganic waste. This situation increases volume weight and specific weight of MSW compost. Maize straw has the highest porosity value $(96.56 \%)$, while the lowest porosity value $(71.55 \%)$ was determined in peat. The highest air capacity was observed in tea waste $(76.73 \%)$ while the lowest is observed in municipal waste compost $(23.1 \%)$. The volume change of growing media after drying, expressed as shrinkage value, is most pronounced in peat with $31.99 \%$, while it is least pronounced in saw dust with $15.27 \%$. Up to $30 \%$ of shrinkage in pot plant growing media is tolerated (Abad et al., 2001). Since shrinkage means the reaction of the material filled in the pot to getting compact, as well (Hicklenton et al., 2001), in comparison with the peat, all samples can be said to be durable to getting compact (Table 2). At the same time, when analyzing shrinkage results, a significant decrease in volume is observed after drying rice hull and spend mushroom compost.

Seeing as growing media is used for plant production, among its most important properties are water holding capacity and wettability. According to the results shown in Table 3, all the samples' water holding capacity values differ slightly comparing to the desired ideal value, while the wettability values are found to be within the ideal value span. The highest water holding capacity value is $458 \mathrm{ml} / 1$ and it is found in peat, while the lowest water holding capacity is $89 \mathrm{ml} / \mathrm{l}$ and it is found in rice hull sample. The 
samples with particle size distribution and porosity values similar to peat such as tea waste and spend mushroom compost are found to have low water holding capacity comparing to peat. The reason for this is thought to be the difference in pore size distribution of the analyzed samples (Paredes et al., 1999).

Table 2. Physical properties of organic waste samples, MSW compost and peat

\begin{tabular}{c|c|c|c|c|c}
\hline Samples & $\begin{array}{c}\text { Bulk density } \\
\left(\mathbf{g} / \mathbf{c m}^{\mathbf{3}}\right)\end{array}$ & $\begin{array}{c}\text { Particular } \\
\text { density }\left(\mathbf{g} / \mathbf{c m}^{3}\right)\end{array}$ & $\begin{array}{c}\text { Porosity } \\
(\boldsymbol{\%} \mathbf{V} / \boldsymbol{V})\end{array}$ & $\begin{array}{c}\text { Air capacity } \\
(\boldsymbol{\%} \mathbf{V} \boldsymbol{V})\end{array}$ & $\begin{array}{c}\text { Shrinkage } \\
(\boldsymbol{\%} \mathbf{V} / \boldsymbol{V})\end{array}$ \\
\hline Hazelnut husk & $0.169 \mathrm{c}^{*}$ & $1.489 \mathrm{f}$ & $88.91 \mathrm{~d}$ & $55.12 \mathrm{~d}$ & $16.12 \mathrm{~h}$ \\
Sawdust & $0.172 \mathrm{c}$ & $1.508 \mathrm{e}$ & $88.72 \mathrm{~d}$ & $50.71 \mathrm{e}$ & $15.27 \mathrm{i}$ \\
Tea waste & $0.076 \mathrm{e}$ & $1.502 \mathrm{e}$ & $94.21 \mathrm{~b}$ & $76.73 \mathrm{~b}$ & $17.21 \mathrm{~g}$ \\
Maize straw & $0.050 \mathrm{f}$ & $1.474 \mathrm{f}$ & $96.56 \mathrm{a}$ & $76.09 \mathrm{~b}$ & $21.13 \mathrm{e}$ \\
Pine bark & $0.177 \mathrm{c}$ & $1.489 \mathrm{f}$ & $88.21 \mathrm{e}$ & $56.42 \mathrm{c}$ & $18.82 \mathrm{f}$ \\
Rice hull & $0.099 \mathrm{~d}$ & $1.524 \mathrm{~d}$ & $93.47 \mathrm{c}$ & $84.53 \mathrm{a}$ & $24.99 \mathrm{c}$ \\
Spend mushroom compost & $0.178 \mathrm{c}$ & $1.614 \mathrm{c}$ & $89.02 \mathrm{~d}$ & $44.45 \mathrm{f}$ & $25.55 \mathrm{~b}$ \\
MSW compost & $0.649 \mathrm{a}$ & $2.089 \mathrm{a}$ & $68.92 \mathrm{~g}$ & $23.11 \mathrm{~g}$ & $21.93 \mathrm{~d}$ \\
Peat & $0.458 \mathrm{~b}$ & $1.856 \mathrm{~b}$ & $73.28 \mathrm{f}$ & $27.72 \mathrm{~h}$ & $31.99 \mathrm{a}$ \\
\hline Ideal values & $<0.40$ & $1.4-2.0$ & $>80$ & $20-30$ & $<30$ \\
\hline
\end{tabular}

*Data followed by the same letter are not different at $\mathrm{p}=0.05$

Table 3. Hydraulic properties of organic waste samples, MSW compost and peat

\begin{tabular}{c|c|c}
\hline Samples & Water holding capacity $(\boldsymbol{m l} / \mathbf{l})$ & Wettability $($ min $)$ \\
\hline Hazelnut husk & $335 \mathrm{~d}^{*}$ & $1.52 \mathrm{~d}$ \\
Sawdust & $379 \mathrm{c}$ & $1.38 \mathrm{e}$ \\
Tea waste & $182 \mathrm{~g}$ & $<1 \mathrm{~g}$ \\
Maize straw & $205 \mathrm{f}$ & $<1 \mathrm{~g}$ \\
Pine bark & $320 \mathrm{e}$ & $1.32 \mathrm{f}$ \\
Rice hull & $89 \mathrm{~h}$ & $<1 \mathrm{~g}$ \\
Spend mushroom compost & $446 \mathrm{~b}$ & $2.59 \mathrm{c}$ \\
MSW compost & $456 \mathrm{a}$ & $3.46 \mathrm{a}$ \\
Peat & $458 \mathrm{a}$ & $3.28 \mathrm{~b}$ \\
\hline Ideal values & $600-1000$ & $<5$ \\
\hline
\end{tabular}

*Data followed by the same letter are not different at $\mathrm{p}=0.05$

The highest value of wettability is found in MSW compost (3.46 min) and the lowest is $<1 \mathrm{~min}$ and was observed in maize straw, tea waste and rice hull samples. However, this is due to the high porosity values of these samples which obstructs the samples form holding water and causes them to be drained fast. Organic substances are believed to have enhanced wettability due to increased porosity (Beardsell and Nichols, 1982). This is why we could say that maize straw, tea waste and rice hull samples' water holding capacity could not be determined and that their wetting period is much longer than the ideal values needed for growing media.

Physiochemical properties of the organic waste samples researched for their potential to be used as a growing media are presented in Table 4. According to these results, the 
highest $\mathrm{pH}$ value is 7.57 and is found in rice hull, while the lowest $\mathrm{pH}$ value is 4.82 and is found in hazelnut husk.

Table 4. Chemical properties of organic waste samples, MSW compost and peat

\begin{tabular}{c|c|c|c}
\hline Samples & $\mathbf{p H}$ & $\mathbf{E C}(\mathbf{m S} / \mathbf{c m})$ & Organic matter content (\%) \\
\hline Hazelnut husk & $4.82 \mathrm{~g}^{*}$ & $2.975 \mathrm{~b}$ & $94.22 \mathrm{~b}$ \\
Sawdust & $6.47 \mathrm{e}$ & $0.202 \mathrm{i}$ & $91.49 \mathrm{~d}$ \\
Tea waste & $5.52 \mathrm{f}$ & $0.532 \mathrm{~g}$ & $92.42 \mathrm{c}$ \\
Maize straw & $7.15 \mathrm{c}$ & $0.582 \mathrm{f}$ & $96.37 \mathrm{a}$ \\
Pine bark & $5.47 \mathrm{f}$ & $0.762 \mathrm{e}$ & $94.39 \mathrm{~b}$ \\
Rice hull & $7.57 \mathrm{a}$ & $0.315 \mathrm{~h}$ & $89.24 \mathrm{e}$ \\
Spend mushroom compost & $7.3 \mathrm{~b}$ & $1.68 \mathrm{~d}$ & $77.65 \mathrm{f}$ \\
MSW compost & $7.3 \mathrm{~b}$ & $2.887 \mathrm{c}$ & $32.38 \mathrm{~h}$ \\
Peat & $6.92 \mathrm{f}$ & $3.46 \mathrm{a}$ & $51.7 \mathrm{~g}$ \\
\hline Ideal values & $5.2-6.3$ & $0.75-3.49$ & $>85$ \\
\hline
\end{tabular}

*Data followed by the same letter are not different at $\mathrm{p}=0.05$

At the same time, from all the samples taken, only pine bark and tea waste have $\mathrm{pH}$ values within the ideal value range. On the other hand, the highest EC value is $4.1 \mathrm{mS} / \mathrm{cm}$ found in raw peat. The lowest EC value is 1.68 seen in spend mushroom compost. According to the results of organic matter analysis, the highest value is $96.87 \%$ in maize straw, while the lowest organic matter value is $32.38 \%$ in municipal waste compost. Also, sample with the lowest organic matter value, that is municipal waste compost, together with spend mushroom compost $(77.65 \%)$ and peat $(51.7 \%)$ were found to have organic matter value below the ideal value range.

\section{Conclusion}

It is determined by this study that the physical and hydraulic properties of the growth media obtained from organic wastes vary with the particle size distribution as well as the surface and interior structures of the organic wastes used. However the results obtained from examined samples has shown that hazelnut husk, sawdust, spend mushroom compost and MSW compost from among the samples examined can be used purely, and that other organic wastes can be used in the mixtures which will be prepared as growth medium components. But because of the low water holding capacities and water redrawing difficulties during the use of the growth mediums consisted of those wastes, it is important to make a good watering program and not to allow drying. It is considered that especially the wastes of corn straw and rice hull can be useful in improving the significant physical properties - such as porosity, air capacity and water holding capacity - of plant growth mediums which will be prepared.

\section{REFERENCES}

[1] Abad, M., Fornes, F., Carrion, C., Noguera, V. (2005): Physical properties of various coconut coir dusts compared to peat. - Hortscience 40: 2138-2144. 
[2] Abad, M., Noguera, P., Bures, S. (2001): National inventory of organic wastes for use as growing media for ornamental potted plant production: case study in Spain. Bioresource Technology 77: 197-200.

[3] Abad, M., Noguera, P., Puchades, R., Maquieira, A., Noguera, V. (2003): Physicochemical and chemical properties of some coconut coir dusts for use as a peat substitute for containerised ornamental plants. - Bioresource Technology 82: 241-245.

[4] Apaolaza, L. H., Gasco, A. M., Gasco, J. M., Guerrero, F. (2005): Reuse of waste materials as growing media for ornamental plants. - Bioresource Technology 96: 125131.

[5] Australian Standard (2003): Potting Mixes, AS 3743-1993. - Standards Australia International, Sydney.

[6] Beardsell, D. V., Nichols, D. G. (1982): Wettability properties of dried out nursery container media. - Sci. Horticult. 17: 49-59.

[7] Belda, R. M., Mendoza Hernández, D., Fornes, F. (2013): Nutrient rich compost versusnutrient poor vermicompostas growth media for ornamental plant production. $-\mathrm{J}$. Plant Nutr. Soil Sci. 176: 827-835.

[8] Benito, M., Masaguer, A., Molıner, A., De Antonıor, R. (2006): Chemical and physical properties of pruning waste compost and their seasonal variability. - Bioresource Technology 97: 2071-2076.

[9] Dede, O. H., Koseoglu, G., Ozdemir, S., Celebi, A. (2006): Effects of organic wastes substrates on the growth of impatients. - Turkish Journal of Agriculture and Forestry 30: 375-381.

[10] European Standard 13037. (1999): Determination of pH. In: Soil Improvers and Growing Media. European Committee for Standardization, Brussels.

[11] Fornes, F., Belda, R. M., Abad, M., Noguera, P., Puchades, R., Maquieira, A., Noguera, V. (2003): The microstructure of coconut coir dusts for use as alternatives to peat in soilless growing media. - Australian Journal of Experimental Agriculture 43: 1171-1179.

[12] Fornes, F., Belda, R. M., Carrion, C., Noguera, V., Garcia-Agustin, P., Abad, M. (2007): Pre-conditioning ornamental plants to drought by means of saline water irrigation as related to salinity tolerance. - Scientia Horticulturae 113: 52-59.

[13] Guo, Z., Liu, W. (2007): Biomimic from the superhdyrophobic plant leaves in nature: Binary structure and unitary structure. - Plant Science 172: 1103-1112.

[14] Hicklenton, P. R., Rodd, V., Warman, P. R. (2001): The effectiveness and consistency of source-separated municipal solid waste and bark composts as components of container growing media. - Scientia Horticulturae 91: 365-378.

[15] Marianthi, T. (2006): Kenaf (Hibiscus cannabinus L.) core and rice hulls as components of container media for growing Pinus halepensis M. Seedlings. - Bioresource Technology 97: 1631-1639.

[16] Masaphy, S., Zabari, L., Pastrana, J., Dultz, S. (2009): Role of fungal mycelium in the formation of carbonate concretions in growing media - an investigation by SEM and synchrotron-based X-ray tomographic microscopy. - Geomicrobiology Journal 26: 442450.

[17] Ozdemir, S., Dede, O., Celebi, A. (2015): Improvement of the wettability properties of compost using seaweed. - Compost Science and Utilization 23: 87-93.

[18] Paredes, C., Cegarra, J., Roig, A., Sfinchez-Monedero, M. A., Bernal M. P. (1999): Characterization of olive mill wastewater (alpechin) and its sludge for agricultural purposes. - BioresourceTechnology 67: 111-115.

[19] Richards, D., Lane, M., Beardsell, D. V. (1986): The influence of particle-size distribution in pinebark:sand:brown coal potting mixes on water supply, aeration and plant growth. - Scientia Hort. 29: 1-14.

[20] Rigane, M. K., Michel, J. M., Medhioub, K., Morel, P. (2011): Evaluation of compost maturity, hydrophysical and physicochemical properties: indicators for use as a component of growing media. - Compost Science \& Utilization 19: 226-234. 
[21] Tariq, U., Rehman, S., Khan, M. A., Younis, A., Yaseen, M., Ahsan, M. (2012): Agricultural and municipal waste as potting media components for the growth and flowering of Dahlia hortensis 'Figaro'. - Turk J Bot 36: 378-385.

[22] Yahya, A., Sye, C. P., Ishola, T. A., Suryanto, H. (2010): Effect of adding palm oil mill decanter cake slurry with regular turning operation on the composting process and quality of compost from oil palm empty fruit bunches. - Bioresource Technology 101: 8736-874. 